\title{
Role of the periodic table in discovery of new elements
}

\author{
By D. C. Hoffman ${ }^{1,2, *}$ \\ ${ }^{1}$ Nuclear Science Division, Lawrence Berkeley National Laboratory, Berkeley, CA 94720, USA \\ 2 College of Chemistry, University of California, Berkeley, CA 94720-1460, USA
}

(Received January 25, 2010; accepted in revised form October 12, 2010)

1869 Periodic Table / Mendeleev / Atomic weight / Atomic number / Element 101 / Atom-at-a-time chemistry

Summary. This year (2009) marks the $140^{\text {th }}$ Anniversary of Mendeleev's original 1869 periodic table of the elements based on atomic weights. It also marks the $175^{\text {th }}$ anniversary of his birth in Tolbosk, Siberia. The history of the development of periodic tables of the chemical elements is briefly reviewed beginning with the presentation by Dmitri Mendeleev and his associate Nikolai Menshutkin of their original 1869 table based on atomic weights. The value, as well as the sometimes negative effects, of periodic tables in guiding the discovery of new elements based on their predicted chemical properties is assessed. It is noteworthy that the element with $Z=101$ (mendelevium) was identified in 1955 using chemical techniques. The discoverers proposed the name mendelevium to honor the predictive power of the Mendeleev Periodic Table. Mendelevium still remains the heaviest element to have been identified first by chemical rather than nuclear or physical techniques. The question concerning whether there will be a future role for the current form of the periodic table in predicting chemical properties and aid in the identification of elements beyond those currently known is considered.

\section{Introduction}

Ever since ancient times, humans have been investigating the composition of the earth around them and observing and even noting the behavior of the stars and other phenomena in the heavens beyond their reach. In the $4^{\text {th }}$ century B.C. Aristotle proposed that all matter was composed of various proportions of the "elements" air, earth, fire, and water.

This year (2009) marks the $140^{\text {th }}$ anniversary of the presentation to the Russian Chemical Society meeting in St. Petersburg by Dmitri Ivanovich Mendeleev and his associate Nikolai Menshutkin of their original Periodic Table of the Elements which was based on atomic weights. (It also marks the $175^{\text {th }}$ anniversary of Mendeleev's birth in Tolbosk, Siberia as the youngest child in a family of 17!) As we consider how to synthesize new elements beyond those currently reported, it is appropriate to review the development of our modern periodic table of the chemical elements and whether or not it will help us in the future isolation and iden-

\footnotetext{
*E-mail: dmhoffman@att.net
}

tification of new chemical elements beyond those currently known [1,2].

\section{Evolution of chemical periodic tables}

Mendeleev and Menshutkin postulated that the 66 elements known in 1869 showed periodicity in their chemical properties when they were arranged in order of their masses as shown in Table 1.

Many chemists in other countries $[3,4]$ had earlier observed "orderliness" in the elements. A few examples are: (Germany) J. W. Dobereiner and his triads: 1829; (USA) O. W. Gibbs (1845) \& J. P. Cooke Jr. (1854); (England) J. A. Newlands and the "Law of Octaves"; (France) A. de Chantcourtois and the "telluric screw" (1869).

The 1871 Periodic Table of Mendeleev shown in Fig. 1 includes subsequent changes to the original 1869 table.

Table 1. 1869 Periodic Table of Mendeleev and Menshutkin (included in text).

\begin{tabular}{|c|c|c|c|c|c|}
\hline & & & $\mathrm{Ti}=\mathbf{5 0}$ & $\mathrm{Zr}=90$ & $?=180$ \\
\hline & & & $\mathrm{V}=51$ & $\mathrm{Nb}=94$ & $\mathrm{Ta}=182$ \\
\hline & & & $\mathrm{Cr}=52$ & $M o=96$ & $\mathrm{~W}=186$ \\
\hline & & & $\mathrm{Mn}=55$ & $\mathrm{Rh}=104,4$ & $\mathrm{Pt}=197,4$ \\
\hline & & & $\mathrm{Fe}=56$ & $\mathrm{Ru}=104,4$ & $\mathrm{Ir}=198$ \\
\hline & & & $\mathrm{Ni}=\mathrm{Co}=59$ & $\mathrm{Pd}=106,6$ & $\mathrm{Os}=199$ \\
\hline \multirow[t]{7}{*}{$\mathrm{H}=1$} & & & $\mathrm{Cu}=63,4$ & $\mathrm{Ag}=108$ & $\mathrm{Hg}=200$ \\
\hline & $\mathrm{Be}=9,4$ & $\mathrm{Mg}=24$ & $\mathrm{Zn}=65,2$ & $\mathrm{Cd}=112$ & \\
\hline & $\mathrm{B}=11$ & $\mathrm{Al}=27,4$ & $?=68$ & $\mathrm{Ur}=116$ & $\Delta \mathbf{u}=197 ?$ \\
\hline & $\mathrm{C}=12$ & $\mathrm{Si}=28$ & $?=70$ & $\mathrm{Sn}=118$ & \\
\hline & $\mathrm{N}=14$ & $\mathrm{P}=31$ & $A s=75$ & $\mathrm{Sb}=122$ & $\mathrm{Bi}=210 ?$ \\
\hline & $\mathrm{O}=16$ & $\mathrm{~S}=32$ & $\mathrm{Se}=79,4$ & $\mathrm{Te}=128 ?$ & \\
\hline & $\mathrm{F}=19$ & $\mathrm{Cl}=35,5$ & $\mathrm{Br}=80$ & $\mathrm{~J}=127$ & \\
\hline \multirow[t]{6}{*}{$\mathrm{Li}=7$} & $\mathrm{Na}=23$ & $\mathrm{~K}=39$ & $\mathrm{Rb}=85,4$ & $\mathrm{Cs}=133$ & $\mathrm{~T} 1=204$ \\
\hline & & $\mathrm{Ca}=40$ & $\mathrm{Sr}=87,6$ & $\mathrm{Ba}=137$ & $\mathrm{~Pb}=207$ \\
\hline & & $?=45$ & $\mathrm{Ce}=92$ & & \\
\hline & & $? \mathrm{Er}=56$ & $\mathrm{La}=94$ & & \\
\hline & & $? \mathrm{Yt}=60$ & $\mathrm{Di}=95$ & & \\
\hline & & $? \operatorname{In}=75,6$ & $\mathrm{Th}=118 ?$ & & \\
\hline
\end{tabular}




\section{PERIODIC' TABLE OF MENDELEEV, INCLUDING CHANGES TO ORIGINAL 1869 TABLE}

\begin{tabular}{|c|c|c|c|c|c|c|c|c|}
\hline [31] & Tpynna 1 & Гpyna 11 & rpynna III & rpyna IV & Грyma $\mathrm{V}$ & Грyuna vı & Гpynna VII & $\begin{array}{c}\text { Tpynna VIII. } \\
\text { nepexod i ri,ynne 1 }\end{array}$ \\
\hline $\begin{array}{l}\text { Tипические } \\
\text { әлемевты }\end{array}$ & $\begin{array}{l}\mathrm{H}=1 \\
\mathrm{Li}=7\end{array}$ & $\mathrm{Be}_{\mathrm{e}}=9,4$ & $B=11$ & $\mathrm{C}=12$ & $N=14$ & $O=16$ & $F=f y$ & \\
\hline $\int$ Ряд 1-й & $\mathrm{Na}=23$ & $\mathrm{Mg}=24$ & $A]=27,3$ & $S i=2 x$ & $P=31$ & $\mathrm{~S}=32$ & $\mathrm{Cl}=35,5$ & \\
\hline E) & $K=39$ & $\mathrm{Ca}=40$ & $-=44$ & $\mathrm{Ti}=5 \mathrm{w} ?$ & $v=j l$ & $\mathrm{Cr}=52$ & $M n=55$ & $\begin{array}{c}\mathrm{Fe}=56, \mathrm{Co}=59, \\
\mathrm{Ni}=59, \mathrm{Cu}=63\end{array}$ \\
\hline$-3-$ й & $(\mathrm{Cu}=63)$ & $\mathrm{Zn}=65$ & $-=6 \mathrm{~s}$ & $-=72$ & $A s=75$ & $\mathrm{Se}=78$ & $\mathrm{Br}=80$ & \\
\hline $\begin{array}{l}\mid-4-\text { } \\
\int-5 \text {-й }\end{array}$ & $\begin{array}{l}\mathrm{Ab}=85 \\
(\mathrm{Ag}=10 \mathrm{~s})\end{array}$ & $\begin{array}{l}\text { Sr }=87 \\
\cdot C d=112\end{array}$ & $\left(\begin{array}{r}(? \mathrm{Yt}=88 ?) \\
\text { In }=113\end{array}\right.$ & $\begin{array}{l}\mathrm{Zr}=90 \\
\mathrm{Sn}=118\end{array}$ & $\begin{array}{l}\mathrm{Nb}=94 \\
\mathrm{Sb}=122\end{array}$ & $\begin{array}{l}M 0=96 \\
T e=128 ?\end{array}$ & $\begin{array}{r}-=100 \\
J=127\end{array}$ & 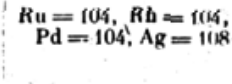 \\
\hline 彭 & $C_{s}=133$ & $B a=137$ & $-=13 i$ & $\mathrm{Ce}=138 ?$ & - & - & - & $-\quad \div$ \\
\hline$\left\{\begin{array}{l}-7-\tilde{u} \\
-8-\tilde{u}\end{array}\right.$ & - & - & $=-$ & - & $\mathrm{Ta}=182$ & $w=184$ & - & $\begin{array}{l}\text { Os }=199 ?, \quad \mathrm{r}=198 ? \\
\mathrm{Pt}=197 ?, \mathrm{Au}=19 ;\end{array}$ \\
\hline - 9-吕 & $(A u=197)$ & $\mathrm{Hg}=200$ & $\mathrm{Tl}=204$ & $\mathrm{~Pb}=207$ & $B i=208$ & - & - & \\
\hline 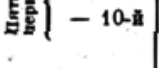 & - & & - & $\mathrm{Th}=232$ & - & $\mathrm{Ur}=240$ & - & \\
\hline $\begin{array}{c}\text { Выстая соли- } \\
\text { нан окись } \\
\text { В }\end{array}$ & $\mathbf{R}^{20}$ & $\begin{aligned} \mathrm{H}^{2} \mathrm{O}^{2} \\
\mathrm{a}\end{aligned}$ & $\mathrm{R}^{2} \mathrm{O}^{3}$ & $\begin{array}{c}\mathrm{H}^{2} \mathrm{O}^{4} \\
\text { ตлก } \\
\mathrm{HO}^{2}\end{array}$ & $e^{\mathrm{R}^{2} \mathrm{O}^{5}}$ & $\begin{array}{c}\mathrm{R}^{2} \mathrm{O}^{6} \\
\text { แI1и } \\
\mathrm{RO}^{3}\end{array}$ & $\mathbf{R}^{2} \mathrm{O}^{-}$ & $\mathrm{H}^{2} \mathrm{O}^{8}$ a:n $\mathrm{RO4}$ \\
\hline $\begin{array}{l}\text { Bacmee водо- } \\
\text { родаое соедан- } \\
\text { нение }\end{array}$ & & & $\left(\mathrm{R}^{\mathrm{5}} \mathrm{5}\right.$ ? $)$ & $\mathrm{RH}^{4}$ & $\mathrm{RH}^{3}$ & $\mathrm{RH}^{2}$ & RH & $1 \quad-$ \\
\hline
\end{tabular}

Fig. 1. 1871 Periodic Table of Mendeleev, including changes to original 1969 table.
Lothar Meyer in Germany proposed a similar scheme in 1970 so why did the Mendeleev Table gain such wide acceptance? This is probably because Mendeleev not only showed the periodicity of the known elements, but stated that his method of classification illustrated a fundamental law of nature. Furthermore, he claimed that apparent "deficiencies" in his table were actually due to gross inaccuracies in atomic weight measurements or to elements that had not yet been discovered! He even went so far as to predict new elements with atomic weights of 44, 68, and 72, their placement in his periodic table, and their general chemical properties. These were scandium-45, gallium-70, and germanium-73 as we now know them. These bold predictions were not completely accepted until scandium, gallium, and germanium were found in nature between 1875 and 1896. The many subsequent experimental proofs of his predictions of new elements gained general acceptance for his periodic system.

Quoting from Glenn Seaborg's address [4] at the Mendeleev Centennial, November 1969, "Whenever one of my periodic tables has been published in a technical journal, a popular magazine, or even the New York Times, I receive a wealth of correspondence from those who are aficionados of periodic tables and who have invented their own versions. This must be one of the most popular hobbies of scientifically inclined people. I caution you that if you have a mind to make your own predictions of what the periodic table of the future will be like, you must be prepared to defend it against all comers, just as Mendeleev had to do one hundred years ago."

By 1910, the number of known elements had risen to 85 . Based on the discoveries of J. J. Thomson, E. Rutherford, Niels Bohr, H. G. J. Moseley and others, the atomic num-

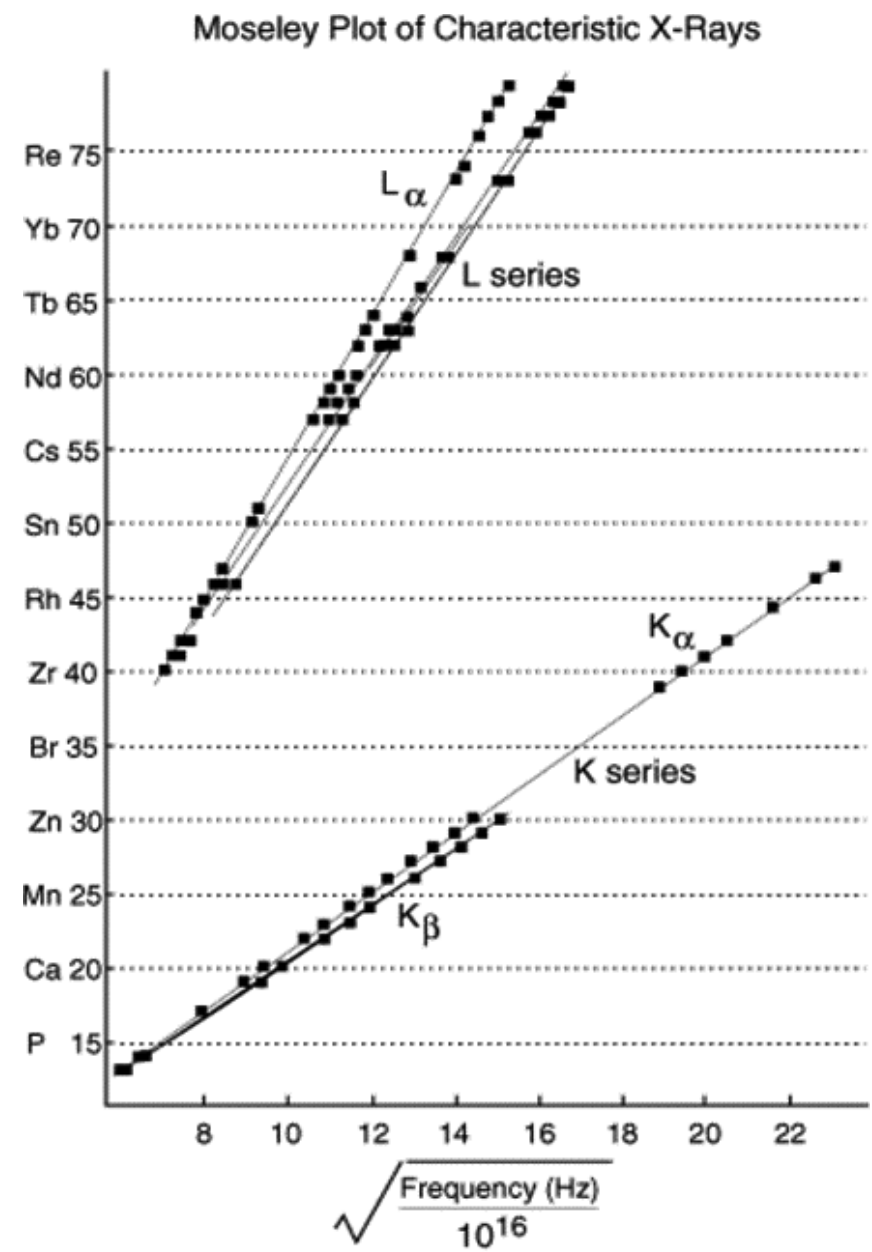

Adapted from Moseley's original data (H. G. J. Moseley, Philos. Mag. (6) 27:703, 1914)

Fig. 2. Moseley figure. 


\section{PERIODIC TABLE OF 1923 SHOWING ELEMENTS BEYOND URANIUM AND WITH TRANSITION SERIES BEGINNING WITH ELEMENT 94}

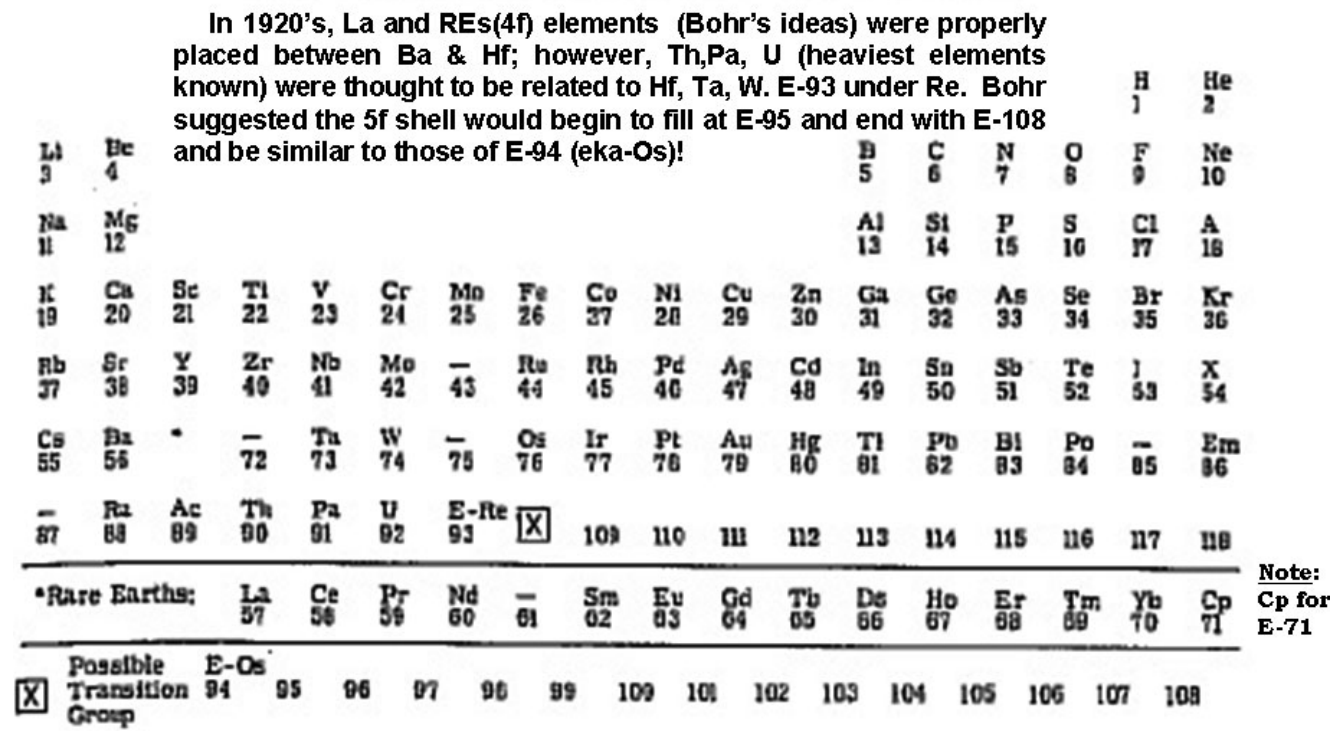

Fig. 3. 1923 Periodic Table of Niels Bohr. ber (proton number or electrical charge on the nucleus) soon replaced the atomic weight as the basis for ordering.

H. G. J. Moseley's ingenious experimental measurements of the characteristic X-rays emitted from an element when it is irradiated by cathode rays showed that their frequencies were related to whole numbers (see Fig. 2). Moseley then brilliantly concluded that these ordinal numbers were equal to the charge on the central nucleus. When the elements were arranged according to these numbers the order differed slightly from Mendeleev's arrangement by atomic weight, and accounted for some of the discrepancies in Mendeleev's periodic table. His original article [5] is a comprehensive masterpiece.

The 1923 periodic table shown in Fig. 3 incorporates Niels Bohr's ideas that the lanthanides and rare earth $(4 f)$ elements should be placed between $\mathrm{Ba}$ and $\mathrm{Hf}$. Th, $\mathrm{Pa}$, and $\mathrm{U}$, the heaviest elements known then were believed to be related to Hf, Ta, and $\mathrm{W}$ and were placed under them, and the undiscovered element 93 was then placed under Re. N. Bohr suggested that the $5 f$ shell would begin to fill at element 95 and end with 108 and have properties similar to those of element 94 (eka-osmium). In fact, the usual form of the periodic table just before World War II still placed Ac, Th, Pa, $\mathrm{U}$, and elements 93-100 in the last row of the periodic table under $\mathrm{Re}, \mathrm{Os}$, Ir, through $\mathrm{Pb}$.

In spite of this, E. M. McMillan and P. H. Abelson reported the first discovery of a transuranium element in 1940, identified in experiments performed when they were originally attempting to investigate the newly discovered phenomenon of nuclear fission. They found a new short-lived beta-activity and postdoc Phil Abelson devised a chemical procedure for its separation. The new element 93 was then identified and shown to have properties similar to uranium (not to $\mathrm{Re}$ ) and was named neptunium, after the planet Neptune, next planet beyond Uranus. The article was published [6] in the 1940 issue of Physical Review, prior to the US entry into WW-II.
Table 2. List of IUPAC approved names for trans-fermium elements

\begin{tabular}{|c|c|c|}
\hline \multicolumn{3}{|c|}{$\begin{array}{c}\text { IUPAC APPROVED HEAVY ELEMENT NAMES } \\
\text { August 30, 1997, Geneva, Switzerland }\end{array}$} \\
\hline Element & Name & Symbol \\
\hline 101 & Mendelevium & Md \\
\hline 102 & Nobelium & No \\
\hline 103 & Lawrencium & $L r$ \\
\hline \multicolumn{3}{|c|}{ Transactinides (TANs) } \\
\hline 104 & Rutherfordium & $\mathrm{Rf}$ \\
\hline 105 & Dubnium (Hahnium)* & $\mathrm{Db}(\mathrm{Ha})^{*}$ \\
\hline 106 & Seaborgium & $\mathrm{Sg}$ \\
\hline 107 & Bohrium & $\mathrm{Bh}$ \\
\hline 108 & Hassium & Hs \\
\hline 109 & Meitnerium & Mt \\
\hline $110 *$ & Darmstadtium & Ds \\
\hline $111^{* *}$ & Roentgenium & $\mathbf{R g}$ \\
\hline $112^{* * *}$ & Copernicium & $\mathrm{Cn}$ \\
\hline \multicolumn{3}{|c|}{$\begin{array}{l}\text { "Many publications of chemical studies before } 1997 \text { use hahnium (Ha) for } 105 \\
\text { *Approved by IUPAC, August 2003; }{ }^{* *} \text { Approved by IUPAC, November } 2004 . \\
* * * \text { Approval Spring 2010?? }\end{array}$} \\
\hline
\end{tabular}

Plutonium (element 94) was identified [6] in 1940-41 by McMillan, J. W. Kennedy, A. C. Wahl, and G. T. Seaborg, but was the discovery was voluntarily withheld from publication until after the end of WW-II. It was named plutonium after Pluto, the next planet beyond Neptune, following the above convention. (Although recently it has been deemed that Pluto may not actually be a planet, it is unlikely that plutonium will be renamed!)

The properties of $\mathrm{U}, \mathrm{Np}$, and $\mathrm{Pu}$ were found to be quite similar and not like W, Re, and Os. The Seaborg group's original search for elements 95 and 96 based on chemical properties similar to those of $\mathrm{U}, \mathrm{Np}$, and $\mathrm{Pu}$ failed. Seaborg then conceived the idea that the elements beyond Ac were part of an actinide series that should be placed in the periodic table under the known lanthanide series. His original Periodic Table published in Chem. \& Eng. News in 1945 


\begin{tabular}{|c|c|c|c|c|c|c|c|c|c|c|c|c|c|c|c|c|c|c|}
\hline $\begin{array}{c}1 \\
H \\
1.008 \\
\end{array}$ & \multicolumn{16}{|c|}{$\begin{array}{l}\text { PERIODIC TABLE SHOWING HEAVY ELEMENTS } \\
\text { AS MEMBERS OF AN ACTINIDE SERIES }\end{array}$} & \multirow{2}{*}{\begin{tabular}{|c|}
$\mathbf{1}$ \\
$\mathrm{H}$ \\
1.008 \\
$\mathbf{9}$ \\
$\mathbf{F}$ \\
19.00 \\
\end{tabular}} & \multirow{2}{*}{\begin{tabular}{|c|}
2 \\
$\mathrm{He}$ \\
4.003 \\
10 \\
$\mathrm{Ne}$ \\
20.183 \\
\end{tabular}} \\
\hline \begin{tabular}{|c|c|} 
\\
$L i$ \\
6.940 \\
\end{tabular} & $\begin{array}{l}4 \\
\mathrm{Be} \\
9.02 \\
\end{array}$ & & & Wins & HEN & U1 & Gle & enn? & I. Seal & borg, 1 & 1945 & & \begin{tabular}{|c|}
5 \\
$B$ \\
10.82 \\
\end{tabular} & \begin{tabular}{|c|}
6 \\
$C$ \\
12.010
\end{tabular} & \begin{tabular}{|c|}
7 \\
$N$ \\
14.008 \\
\end{tabular} & $\begin{array}{c}8 \\
0 \\
16.000\end{array}$ & & \\
\hline $\begin{array}{c}11 \\
\mathrm{Na} \\
22.997\end{array}$ & $\begin{array}{c}12 \\
M g \\
24.32 \\
\end{array}$ & $\begin{array}{c}13 \\
\text { A1 } \\
26.97 \\
\end{array}$ & $\mathrm{Ch}$ & $\mathrm{am}$ & $2 \mathrm{Fr}$ & & Jen & NS 1 & 1945 & 23 & 2190 & 3. & \begin{tabular}{c|c|}
13 \\
$A 1$ \\
26.97 \\
\end{tabular} & $\begin{array}{c}14 \\
\mathrm{Si} \\
28.06\end{array}$ & \begin{tabular}{|c|}
15 \\
$P$ \\
30.98 \\
\end{tabular} & $\begin{array}{l}16 \\
S \\
32.06\end{array}$ & $\begin{array}{c}17 \\
\mathrm{Cl} \\
35.457\end{array}$ & $\begin{array}{l}18 \\
\text { A } \\
39.944\end{array}$ \\
\hline $\begin{array}{c}19 \\
K \\
39.096 \\
\end{array}$ & $\begin{array}{l}20 \\
\mathrm{Ca} \\
40.08 \\
\end{array}$ & $\begin{array}{c}21 \\
\mathrm{SC} \\
45.10 \\
\end{array}$ & $\begin{array}{c}22 \\
\mathrm{Ti} \\
4790\end{array}$ & $\begin{array}{c}23 \\
V \\
5095 \\
\end{array}$ & $\begin{array}{c}24 \\
\mathrm{Cr} \\
52.0 \\
\end{array}$ & $\begin{array}{l}25 \\
\mathrm{Mn} \\
54\end{array}$ & 3 & $\begin{array}{c}26 \\
\mathrm{Fe} \\
55.85\end{array}$ & $\begin{array}{c}27 \\
\text { Co } \\
5894\end{array}$ & $\begin{array}{l}28 \\
\mathrm{Ni} \\
5869 \\
\end{array}$ & \begin{tabular}{l|}
29 \\
$\mathrm{Cu}$ \\
63.57
\end{tabular} & \begin{tabular}{|l|}
30 \\
$\mathrm{Zn}$ \\
6538
\end{tabular} & $\begin{array}{l}31 \\
G 0 \\
69.72\end{array}$ & $\begin{array}{l}32 \\
60 \\
72.60\end{array}$ & \begin{tabular}{|c|}
33 \\
$\mathrm{As}$ \\
74.91 \\
\end{tabular} & \begin{tabular}{|c|}
34 \\
$\mathrm{Se}$ \\
78.96
\end{tabular} & \begin{tabular}{|c|}
35 \\
$\mathrm{Br}$ \\
79.916 \\
\end{tabular} & $\begin{array}{l}36 \\
\mathrm{Kr} \\
83.7 \\
\end{array}$ \\
\hline \begin{tabular}{|c|}
37 \\
$R \mathbf{R b}$ \\
85.48 \\
\end{tabular} & $\begin{array}{c}38 \\
S r \\
87.63\end{array}$ & $\begin{array}{c}39 \\
y \\
88.92 \\
\end{array}$ & $\begin{array}{l}40 \\
\mathrm{Zr} \\
91.22 \\
\end{array}$ & $\begin{array}{l}41 \\
\mathrm{Cb} \\
92.91\end{array}$ & $\begin{array}{l}42 \\
\text { Mo } \\
95.9 \\
\end{array}$ & 43 & & $\begin{array}{c}44 \\
R u \\
101.7 \\
\end{array}$ & \begin{tabular}{|c|}
45 \\
$\mathrm{Rh}$ \\
102.91 \\
\end{tabular} & $\begin{array}{c}46 \\
\mathrm{Pd} \\
1067 \\
\end{array}$ & \begin{tabular}{|c|}
47 \\
$\mathrm{Ag}$ \\
107.880 \\
\end{tabular} & $\begin{array}{c}48 \\
\text { Cd } \\
\text { 112.41 } \\
\end{array}$ & \begin{tabular}{|c|}
49 \\
In \\
114.76 \\
\end{tabular} & \begin{tabular}{|c|}
50 \\
$\mathrm{Sn}$ \\
118.70 \\
\end{tabular} & \begin{tabular}{|c|}
51 \\
$S b$ \\
12176 \\
\end{tabular} & \begin{tabular}{|c|}
52 \\
$\mathrm{Te}$ \\
12761 \\
\end{tabular} & \begin{tabular}{|c|}
53 \\
1 \\
126.92 \\
\end{tabular} & $\begin{array}{r}54 \\
\times e \\
131.3 \\
\end{array}$ \\
\hline $\begin{array}{c}55 \\
\text { Cs } \\
132.91 \\
\end{array}$ & $\begin{array}{c}56 \\
\text { Bo } \\
137.36 \\
\end{array}$ & 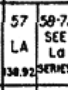 & $\begin{array}{c}72 \\
\mathrm{Hf} \\
178.6 \\
\end{array}$ & $\begin{array}{c}73 \\
\text { To } \\
180.88 \\
\end{array}$ & $\begin{array}{r}74 \\
W \\
1839 \\
\end{array}$ & 186. & & $\begin{array}{c}76 \\
08 \\
1902 \\
9\end{array}$ & \begin{tabular}{|c|}
77 \\
$1 r$ \\
193.1 \\
\end{tabular} & \begin{tabular}{|c|}
78 \\
$\mathrm{Pt}$ \\
195.23 \\
\end{tabular} & $\begin{array}{c}79 \\
A u \\
197.2 \\
\end{array}$ & \begin{tabular}{|l|}
80 \\
$\mathrm{Hg}$ \\
200.61 \\
\end{tabular} & \begin{tabular}{|c|}
81 \\
$T 1$ \\
20439 \\
\end{tabular} & \begin{tabular}{|c|}
82 \\
$\mathrm{~Pb}$ \\
207.21
\end{tabular} & \begin{tabular}{|c|}
83 \\
$8 \mathrm{Bi}$ \\
209.00 \\
\end{tabular} & $\begin{array}{l}84 \\
\text { Po }\end{array}$ & 85 & $\begin{array}{l}86 \\
R n \\
222 \\
\end{array}$ \\
\hline 87 & $\begin{array}{l}88 \\
\text { Ro }\end{array}$ & 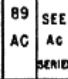 & $\begin{array}{l}90 \\
\mathrm{Th}\end{array}$ & $\mathrm{Po}_{0}$ & & & & 95 & 96 & & & & & & & & & \\
\hline
\end{tabular}

\begin{tabular}{|c|c|c|c|c|c|c|c|c|c|c|c|c|c|c|c|}
\hline $\begin{array}{r}\text { LANTHANIDE } \\
\text { SERIES }\end{array}$ & \begin{tabular}{|c|}
57 \\
Lo \\
138.92 \\
\end{tabular} & \begin{tabular}{|c|}
58 \\
$6 e$ \\
140.13 \\
\end{tabular} & \begin{tabular}{|c|}
59 \\
$\mathrm{Pr}$ \\
140.92 \\
\end{tabular} & \begin{tabular}{|l|}
60 \\
$\mathrm{Nd}$ \\
14427 \\
\end{tabular} & 61 & $\begin{array}{c}62 \\
\mathrm{Sm} \\
150.43 \\
\end{array}$ & $\begin{array}{c}63 \\
\text { Eu } \\
1520 \\
\end{array}$ & \begin{tabular}{|c|}
64 \\
Gd \\
156.9 \\
\end{tabular} & $\begin{array}{c}65 \\
T b \\
159.2 \\
\end{array}$ & \begin{tabular}{|c|}
66 \\
Dy \\
162.46 \\
\end{tabular} & $\begin{array}{l}67 \\
\mathrm{Ho} \\
163.5 \\
\end{array}$ & \begin{tabular}{|c|}
68 \\
$\mathrm{Er}$ \\
167.2 \\
\end{tabular} & $\begin{array}{c}69 \\
\mathrm{Tm} \\
169.4 \\
\end{array}$ & $\begin{array}{c}70 \\
\text { Yb } \\
173.04\end{array}$ & \begin{tabular}{|c|}
71 \\
Lu \\
174.99 \\
\end{tabular} \\
\hline $\begin{array}{r}\text { ACTINIDE } \\
\text { SERIES }\end{array}$ & $\begin{array}{l}89 \\
\mathrm{AC}\end{array}$ & \begin{tabular}{|c|}
90 \\
Th \\
232.12 \\
\end{tabular} & \begin{tabular}{|c|}
91 \\
$\mathrm{Po}$ \\
231 \\
\end{tabular} & \begin{tabular}{|c|}
92 \\
$u$ \\
23807
\end{tabular} & $\begin{array}{l}93 \\
\mathrm{~Np} \\
237 \\
\end{array}$ & $\begin{array}{l}94 \\
\text { Pu }\end{array}$ & 95 & 96 & & & & & & & \\
\hline
\end{tabular}

Fig. 4. Original 1945 Seaborg Table showing actinide series. is shown in Fig. 4. The group then quickly identified elements 96 (Cm) and 95 (Am) as trivalent species in 1944-1945. Thus, we have seen how different versions of the Periodic Table have both hindered and helped in the chemical separation and identification of new chemical elements.

\section{Discovery of element 101 (Mendelevium)}

The chemical separation and identification of the new element 101 in 1955 was a landmark experiment in many respects. It was the first transuranium element separated and identified using atom-at-a-time chemistry - 17 atoms in 8 experiments. It was also the last of the transuranium elements to be discovered and identified using direct radiochemical separation of the element itself. Higher $\mathrm{Z}$ transuranium elements since then have all been first identified using "physical separation techniques" and/or observation of "nuclear" decay properties. In addition, the highly radioactive ${ }^{253}$ Es $(\sim 20 \mathrm{~d}$ half-life $)$ target contained only a few picograms, one of the smallest targets ever used in such experiments.

The paper was published [8] in 1955 in Letters to the Editor of Physical Review by A. Ghiorso, B. G. Harvey, G. R. Choppin, S. G. Thompson, and G. T. Seaborg and was only 2 pages in length! On the second page, the authors wrote, "We would like to suggest the name Mendeleev, symbol Mv, for the new element in recognition of the pioneering role of the great Russian chemist, Dmitri Mendeleev, who was the first to use the periodic system of the elements to predict the chemical properties of undiscovered elements, a principle which has been a key to the discovery of the last seven transuranium (actinide) elements." This name was finally officially approved by IUPAC in 1997 when the symbol was changed to Md.

Table 2 lists the IUPAC approved names for elements with $Z>100$. Note that 112 is the heaviest element whose discovery has been approved by IUPAC and the proposed name copernicium after the Polish astronomer Nicolaus Copernicus and symbol $\mathrm{Cn}$ are now awaiting final approval.

\section{Future role of the periodic table}

In 1968-69, Seaborg proposed a conventional form of the periodic table with a "superactinide" series placed at the bottom under the lanthanide and actinide series. This was done for simplicity's sake to conform as closely as possible to then existing forms of the periodic tables. This 32-member series begins with element 122 and ends with element 153 after filling the $5 g$ (18) and $6 f$ (14) electronic shells, albeit in mixed configurations! Furthermore, intrusions from $7 d$ and $8 p$ electrons may cause significant deviations from expected trivalent properties of this series.

Half-lives and production rates are getting ever smaller although some longer species may be synthesized if we can approach nearer to predicted spherical even stable deformed regions. Much experimental information needs to be acquired and systematized before we abandon our periodic table representations although severe adjustments may be required.

Then what is the future role for a "conventional" periodic table and chemical experimentalists? If suitable isotopes for chemical studies can be produced beyond element 118, then we can determine if they are g-block elements or totally scrambled! It will be essential to compare theoretical predictions of both chemical and nuclear properties with experimental data to guide future experiments. Unique capabilities are now being built for conducting frontier explorations at the limits of both the chemical periodic table and the chart of the nuclides. Such complex and difficult experiments will certainly require international collaborations involving both facilities and personnel on all levels to successfully explore the regions that lie ahead.

In summary, Seaborg's simple conventional periodic table has been a guide for $\sim 40$ years and is still widely used 
in various forms. Other more complicated and "clever" representations have been formulated over the years but are now seldom seen.

\section{References}

1. Hoffman, D. C.: The Periodic Table, J. Chem. Educ. 86, 11221128 (2009).

2. Hoffman, Darleane, C.: Chemistry beyond the actinides. Chapt. 16 in: Radioanalytical Chemistry. (Kahn, B., ed.) Springer Science+ Business Media, LLC, New York, NY, USA (2007), pp. 338-361.
3. Seaborg, G. T., Valens, E. G.: Elements of the Universe. E. P. Dutton \& Co., Inc., New York, USA (1958).

4. Seaborg, G. T.: From Mendeleev to Mendelevium and Beyond. Conf. XIII, The Transuranium Elements - The Mendeleev Centennial, Houston, TX, USA, 17-10 November (1969).

5. Moseley, H. G. J.: Philos. Mag. 6, 27-703 (1914).

6. Hoffman, D. C., Ghiorso, A., Seaborg, G. T.: The Transuranium Elements - the Inside Story. Imperial College Press, London, UK (2000).

7. McMillan, E. M., Abelson, P. H.: Radioactive element 93. Phys. Rev. 57, 1185-1186 (1940)

8. Ghiorso, A., Harvey, B. G., Choppin, G. R., Thompson, S. G., Seaborg, G. T.: New element mendelevium, atomic number 101. Phys. Rev. 98(5), 1518-1519 (1955). 